\title{
The energy cost of fat and protein deposition in the rat
}

\author{
By J. D. PULlaR and A. J. F. WEBSTER \\ Rowett Research Institute, Bucksburn, Aberdeen $A B 2{ }_{9} S B$ \\ (Received 12 March 1976 - Accepted 25 fune 1976)
}

\begin{abstract}
1. Measurements were made of energy balance by direct calorimetry, and of nitrogen balance in groups of lean and congenitally obese ("fatty") Zucker rats at body-weights of 200 and $350 \mathrm{~g}$ given a highly digestible semisynthetic diet at $14^{\circ} \circ$ or $18.4 \mathrm{~g} / \mathrm{rat}$ per $24 \mathrm{~h}$.

2. Losses of food energy and $\mathbf{N}$ in faeces were very small. The fatty rats lost much more $\mathbf{N}$ in urine than did lean rats. Despite this the proportion of gross energy that was metabolized was 0.92 for both fatty and lean rats.

3. In all trials, fatty rats lost a smaller proportion of metabolizable energy (ME) as heat and deposited less as protein than thin rats but deposited much more as fat.

4. The amounts of ME required to deposit $\mathrm{I} \mathrm{kJ}$ of protein and $\mathrm{I} \mathrm{kJ}$ of fat respectively were shown by regression analysis to be $2 \cdot 25( \pm 0.16)$ and $1 \cdot 36( \pm 0.06) \mathrm{kJ}$ respectively. These values agree extremely closely with recent, more tentative, estimates based on assumptions as to maintenance requirement which the present experiments were able to circumvent. It may be concluded with confidence that the energy costs of depositing I $g$ of protein or fat are almost identical at $53 \mathrm{~kJ} \mathrm{ME} / \mathrm{g}$.
\end{abstract}

The energy cost of fat and protein deposition is simply the increment of food energy (usually expressed as metabolizable energy (ME)) required to promote a defined increment in body protein or fat.

The energy cost of fat deposition can be measured with precision in adult animals since, in these circumstances, energy retention as protein is small and the amount of ME required to maintain energy balance (so-called 'maintenance requirement') does not differ much between successive measurements made of metabolic heat production at different levels of ME intake. There is general agreement that in simple-stomached species such as the rat and the pig the energy cost of fat deposition ranges from about $\mathrm{I} \cdot 4 \mathrm{~kJ} \mathrm{ME} / \mathrm{kJ}$ fat deposited for foods consisting predominantly of carbohydrate to $\mathrm{I} \cdot \mathrm{I} 5$ for foods rich in triglycerides (ARC/MRC Committee, 1974).

The energy cost of protein deposition has been more difficult to assess. First, even during rapid growth the amount of energy deposited as protein is small relative to that deposited as fat or dissipated as heat. Second, the division of ME between maintenance requirement and that for protein and fat deposition changes continuously during growth and these changes are linked in such a way that changes in maintenance, protein and fat deposition show marked autocorrelation. Kielanowski (1965) recognized this when first he used multiple regression analysis in an attempt to partition ME intake between maintenance, protein and fat deposition and since then a series of reports has used his approach to describe the efficiencies of protein and fat deposition in pigs (Kielanowski \& Kotarbinska, 1970; Gädeken, Oslage \& Fliegel, 1973; Close, Verstegen \& Mount, 1973; Thorbek, 1970, 1975) and in rats (Schiemann, I970; McCracken \& Weatherup, I973). All these analyses required a priori assumptions to be made concerning the ME requirement for maintenance and since this was 
always the largest single component of the multiple regression equation, small variations in assumed maintenance were shown to lead to bizarre differences in the apparent energy cost of protein deposition (Thorbek, 1970; McCracken \& Weatherup, 1973). Kielanowski (1976), in a critical review of these experiments, concluded recently, however, that a majority view favours a value of about $2 \cdot 3 \mathrm{~kJ} \mathrm{ME} / \mathrm{kJ}$ protein deposited.

In a previous experiment (Pullar \& Webster, 1974) we made use of the large phenotypic difference between congenitally obese (fatty) and lean rats of the Zucker strain (Zucker \& Zucker, I96r) in order to examine the energy costs of deposition of protein, and fat in a way that was not inextricably linked to differences in maintenance requirement. Our estimate of the energy cost of protein deposition was $2 \cdot 32 \mathrm{~kJ} \mathrm{ME} / \mathrm{kJ}$ protein, very similar to the best estimate given by Kielanowski (1976). However, this experiment still depended to some extent on a priori assumptions as to the energy requirement for maintenance.

The present study was designed to confirm (or otherwise) estimates of the energy cost of protein and fat deposition in the rat by an experiment that enabled these costs to be measured in a way that was free from assumptions as to the energy cost of maintenance.

\section{EXPERIMENTAL}

\section{Animals and diet}

A total of thirty-two fatty and forty lean male Zucker rats was used. Fatties could usually be recognized at about $24 \mathrm{~d}$ of age, soon after weaning. In the breeding colony the rats were given a commercial pelleted diet (Oxoid, Herbert C. Styles (Bewdley) Ltd, Bewdley, Worcs.).

Over a period of about $\mathrm{I} 2$ months, eight groups of four fatty rats and ten groups of four lean rats were selected at about $28 \mathrm{~d}$ of age to be as similar in weight as possible. The groups of four fatty rats could not usually be taken from the same litter but birth dates of individuals within a group never differed by more than $2 \mathrm{~d}$.

Each group of four rats was kept in a single cage with a wire mesh floor and remained there for the duration of the experiment. Ambient temperature was maintained at $22^{\circ}$ and a $12 \mathrm{~h}(06.00-18.00$ hours) light-dark cycle was operated.

During the experiment the rats were given a highly digestible semisynthetic diet, the composition of which appears in Table $\mathrm{I}$. This diet was designed to minimize losses of energy and nitrogen in faeces and thereby to minimize uncertainties in balance trials. The rats were weaned from the Oxoid diet to this diet over a period of about Io $\mathrm{d}$ and were eating nothing but the experimental diet by about $40^{\circ} \mathrm{d}$ of age when they weighed on average about $15 \circ \mathrm{g}$. Fresh water was available at all times.

\section{Plan of experiments}

The experimental design emerged from our previous observation that ad lib. intake in Zucker rats remains remarkably constant throughout growth from about I50 to $400 \mathrm{~g}$ body-weight (Pullar \& Webster, 1974). 
Table I. Composition ( $\mathrm{g} / \mathrm{kg})$ of the semisynthetic diet given to rats

Casein
White flour (Bero)
Sucrose
Maize oil (Mazola)
Inorganic salts*
Trace elements $†$
KI in sucroset
Vitamin mix $\$$

$225 \cdot 0$
$325 \cdot 0$
$292 \cdot 5$
$90 \cdot 0$
$38 \cdot 0$
$2 \cdot 0$
$2 \cdot 5$
$25 \cdot 0$

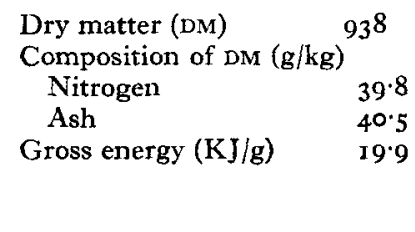

* Contained (g): $\mathrm{Na}_{2} \mathrm{HPO}_{4} 8 \cdot 3, \mathrm{KH}_{2} \mathrm{PO}_{4} 7 \cdot 9, \mathrm{KCl}_{5} \cdot 8, \mathrm{MgCl}_{2} .6 \mathrm{H}_{2} \mathrm{O}_{3} \cdot 3, \mathrm{CaCO}_{3} \mathrm{I}_{2} \cdot 7$.

$\dagger$ Contained (mg): $\mathrm{MnSO}_{4} \cdot 4 \mathrm{H}_{2} \mathrm{O}_{210}, \mathrm{ZnSO}_{4} \cdot 7 \mathrm{H}_{2} \mathrm{O}$ 176, $\mathrm{FeSO}_{4} \cdot 7 \mathrm{H}_{2} \mathrm{O} 260, \mathrm{CuSO}_{4} \cdot 5 \mathrm{H}_{2} \mathrm{O} 98$, made up to $2 \mathrm{~g}$ with sucrose.

$\ddagger$ Containing $32.5 \mathrm{mg} \mathrm{KI}$.

$\S$ Contained $(\mathrm{mg})$ : thiamin $5 \cdot 0$, riboflavin 10 , nicotinic acid 20 , pyridoxine $5 \cdot 0$, pteroylmonoglutamic acid 5.0 , cyanocobalamin 2.5 , calcium pantothenate 80 , biotin 10, myo-inositol 400 , p-aminobenzoic acid ro, choline chloride 10000, ascorbic acid 38 , DL- $\alpha$-tocopheryl acetate 200 , retinyl acetate $4 \cdot 2$, cholecalciferol 0.2 , menaphthone sodium bisulphite 0.5 , made up to $25 \mathrm{~g}$ with sucrose (Spencer's Feed Supplements, Aberdeen).

Groups of fatty (F) and lean (L) rats were 'pair-fed' either $18.4 \mathrm{~g} /$ rat per $24 \mathrm{~h}$ (FH and LH groups) or $14.0 \mathrm{~g} /$ rat per $24 \mathrm{~h}$ (FL and LL groups). The LH group did not eat all their food during the first few days, but all groups were consuming their entire ration by the time of the first balance trials.

Measurements of energy and $N$ balance were made for each group when their average body-weights were 200 and $35^{\circ} \mathrm{g}$. The design of the experiment was therefore such that two phenotypes (fatty or lean) given two rations (high or low) were tested at two stages of growth ( 200 and $35^{\circ} \mathrm{g}$ ).

The cage containing each group of four rats was moved into a gradient-layer calorimeter (Pullar, 1969) in order to measure heat loss over three or four successive periods of $24 \mathrm{~h}$.

The rats were kept in the calorimeter at $22^{\circ}$ for $24 \mathrm{~h}$ before any measurements or collections were begun so that they could adapt to any small change in their environment. It was necessary to use groups of four rats at a time in order to generate sufficient heat $(500-1000 \mathrm{~kJ} / 24 \mathrm{~h}$, or $6-12 \mathrm{~W})$ to obtain acceptable precision from the calorimeter.

Urine was separated from the small amount of faeces and any spilled food using a grid assembly and collected under $2 \mathrm{M}-\mathrm{H}_{2} \mathrm{SO}_{4}$. Faeces were removed daily at I 1.00 hours when the rats were weighed and fed. Acidified urine was removed at the end of the collection period. The energy contents of food and excreta were determined by adiabatic bomb calorimetry. $N$ contents of food, urine and faeces were determined by the macro-Kjeldahl procedure. Food spillage was extremely small. It was greatest with the $\mathrm{FH}$ groups at $8.3 \mathrm{~g} / \mathrm{kg}$ food offered, and least with the LH groups at $5.3 \mathrm{~g} /$ $\mathrm{kg}$. Suitable corrections were made to gross energy (GE) intakes. Faecal collections were not contaminated by spilled food.

When the groups receiving the low ration had completed their balance trials at $200 \mathrm{~g}$, their ration was increased to $18.4 \mathrm{~g} /$ rat per $24 \mathrm{~h}$ until they reached about $300 \mathrm{~g}$, whereupon it was brought back to the low level of $14.0 \mathrm{~g}$ until the rats reached 
Table 2. Losses of food gross energy $(G E)$ and nitrogen in the faeces and urine of fatty and lean Zucker rats at body-weights of 200 and $35^{\circ} \mathrm{g}$

\begin{tabular}{|c|c|c|c|c|c|c|c|c|c|}
\hline \multirow{3}{*}{$\begin{array}{l}\text { Body-wt }(g) \quad \ldots \\
\text { Level of feeding }\end{array}$} & \multicolumn{4}{|c|}{ Fatty rats } & \multicolumn{4}{|c|}{ Lean rats } & \multirow{3}{*}{$\begin{array}{c}\text { Resi- } \\
\text { dual } \\
\text { SD }\end{array}$} \\
\hline & \multicolumn{2}{|c|}{200} & \multicolumn{2}{|c|}{350} & \multicolumn{2}{|c|}{200} & \multicolumn{2}{|c|}{$35^{\circ}$} & \\
\hline & High & Low & High & Low & High & Low & High & Low & \\
\hline $\begin{array}{l}\text { GE loss }(\mathrm{J} / \mathrm{kJ}) \\
\text { Faeces } \\
\text { Urine }\end{array}$ & $\begin{array}{l}26 \\
47\end{array}$ & $\begin{array}{l}27 \\
44\end{array}$ & $\begin{array}{l}30 \\
48\end{array}$ & $\begin{array}{l}29 \\
50\end{array}$ & $\begin{array}{l}33 \\
37\end{array}$ & $\begin{array}{l}3 \mathrm{I} \\
4 \mathrm{I}\end{array}$ & $\begin{array}{l}42 \\
44\end{array}$ & $\begin{array}{l}32 \\
48\end{array}$ & $\begin{array}{l}3.5 \\
3.7\end{array}$ \\
\hline $\begin{array}{l}\text { N loss }(\mathrm{mg} / \mathrm{g}) \\
\text { Faeces } \\
\text { Urine }\end{array}$ & $\begin{array}{r}5^{6} \\
703\end{array}$ & $\begin{array}{r}6 \mathrm{I} \\
73 \mathrm{I}\end{array}$ & $\begin{array}{r}66 \\
780\end{array}$ & $\begin{array}{r}64 \\
863\end{array}$ & $\begin{array}{r}73 \\
523\end{array}$ & $\begin{array}{r}64 \\
612\end{array}$ & $\begin{array}{r}90 \\
678\end{array}$ & $\begin{array}{r}69 \\
786\end{array}$ & $\begin{array}{r}5 \cdot 6 \\
39 \cdot 6\end{array}$ \\
\hline $\begin{array}{l}\text { Ratio, urinary energy : N } \\
(\mathrm{kJ} / \mathrm{g})\end{array}$ & 33 & 30 & $3^{1}$ & 29 & 36 & 34 & 33 & $3^{\mathrm{I}}$ & - \\
\hline $\begin{array}{l}\text { Metabolizability of GE } \\
(\mathrm{J} / \mathrm{kJ})\end{array}$ & 926 & 929 & 922 & 921 & 930 & 928 & 914 & 920 & $4 \cdot 2$ \\
\hline
\end{tabular}

$35 \circ \mathrm{g}$ body-weight. On average the rats took about the same length of time to grow from 300 to $350 \mathrm{~g}$ on $14.0 \mathrm{~g}$ food/d as they did to grow from 200 to $300 \mathrm{~g}$ on $18.4 \mathrm{~g} / \mathrm{d}$ (FL about $19 \mathrm{~d}$, LL about $26 \mathrm{~d}$ for each stage).

\section{RESULTS}

Losses of GE and $\mathrm{N}$ in the urine and faeces of rats are summarized in Table 2. Faecal energy losses were very small, 28 and $34 \mathrm{~J} / \mathrm{kJ} \mathrm{GE}$ for the fatty and lean rats respectively. This difference was statistically significant $(P<0 \circ 01)$. Faecal energy losses were higher at $35^{\circ} \mathrm{g}$ body-weight and the interaction term was also significant, so that losses were highest in the lean rats at $35^{\circ} \mathrm{g}(P<0.0 \mathrm{I})$. Urine energy losses increased with increasing body-weight $(P<0.01)$ but there were no significant differences between phenotypes or rations.

Faecal $\mathrm{N}$ losses showed the same pattern as for faecal losses of energy, being greatest for lean rats at $35^{\circ} \mathrm{g}$. Urinary $\mathrm{N}$ losses were significantly greater for the fatty rats $(P<0.01)$ and at the higher body-weight $(P<0.01)$. This was as expected, but Table 2 also shows that the increased urinary $\mathrm{N}$ loss from the fatties was not associated with a comparable increase in urinary energy loss. In other words, the ratio, urinary energy: urinary $\mathrm{N}$ was lower in fatties, which indicates that the composition of nitrogenous compounds in the urine must have differed between the phenotypes.

Although the small differences between the groups in faecal and urinary losses of energy and $\mathrm{N}$ were statistically significant the effect of these differences on the proportion of $\mathrm{GE}$ that was metabolized by the different groups (metabolizability, Table 2) was negligible, the means ranging from 914 to $930 \mathrm{~J} / \mathrm{kJ}$.

The actual body-weights of the rats at the times of the two balance trials were all extremely close to those planned. At 200 and $350 \mathrm{~g}$ planned weights, actual weights were 201 (SD $2 \cdot 6$ ) and $35^{\circ}(\mathrm{SD} \mathrm{I} \cdot 3$ ) respectively.

Table 3 summarizes the results of the energy and $\mathrm{N}$ balance trials made with each group of rats. Again the residual variation within any group was small. As expected, 
Table 3. Results of energy and nitrogen balance trials made with lean and fatty Zucker rats kept in groups of four at mean body-weights of 200 and $350 \mathrm{~g}$

\begin{tabular}{|c|c|c|c|c|c|c|c|c|c|}
\hline \multirow{3}{*}{$\begin{array}{l}\text { Body-wt }(g) \quad \ldots \\
\text { Level of feeding }\end{array}$} & \multicolumn{4}{|c|}{ Fatty rats } & \multicolumn{4}{|c|}{ Lean rats } & \multirow{3}{*}{$\begin{array}{c}\text { Resi- } \\
\text { dual } \\
\text { SD }\end{array}$} \\
\hline & \multicolumn{2}{|c|}{200} & \multicolumn{2}{|c|}{$35^{\circ}$} & \multicolumn{2}{|c|}{200} & \multicolumn{2}{|c|}{350} & \\
\hline & High & Low & High & Low & High & Low & High & Low & \\
\hline Mid-trial age (d) & 46 & 49 & 74 & 87 & 49 & 54 & 80 & 107 & $3 \cdot 8$ \\
\hline $\begin{array}{l}\text { Metabolizable energy } \\
\text { intake }(\mathrm{kJ} / 24 \mathrm{~h})\end{array}$ & 316 & 241 & $3+5$ & 239 & 318 & $24 I$ & $3^{\top} 3$ & 239 & $I \cdot 4$ \\
\hline Heat loss $(\mathrm{kJ} / 24 \mathrm{~h})$ & $16 r$ & 136 & 185 & r55 & 206 & 175 & 243 & 213 & $5 \cdot 2$ \\
\hline Energy retention $(\mathrm{kJ} / 24 \mathrm{~h})$ & 155 & 105 & 129 & 84 & I I 2 & 66 & 70 & 26 & $5 \cdot 8$ \\
\hline $\mathrm{N}$ retention $(\mathrm{mg} / 24 \mathrm{~h})$ & 163 & 107 & 105 & 38 & 275 & 167 & I 58 & 76 & $25 \cdot 9$ \\
\hline $\begin{array}{l}\text { Energy retained as } \\
\text { protein } *(\mathrm{~kJ} / 24 \mathrm{~h})\end{array}$ & $23 \cdot 9$ & $15 \cdot 8$ & $15 \cdot 4$ & $5 \cdot 6$ & $40 \cdot 5$ & $24 \cdot 5$ & $23 \cdot 3$ & II'2 & $3 \cdot 8$ \\
\hline $\begin{array}{l}\text { Energy retained as fat } \dagger \\
(\mathrm{kJ} / 24 \mathrm{~h})\end{array}$ & $13 \times \cdot 6$ & $89 \cdot I$ & $I_{1} 3^{6} 6$ & $78 \cdot 3$ & $7 x \cdot 7$ & $4 I^{\prime} 7$ & $47 \cdot 1$ & I 5.0 & $6 \cdot 8$ \\
\hline
\end{tabular}

when $\mathrm{ME}$ intake was fixed at two levels, 315 and $240 \mathrm{~kJ} / 24 \mathrm{~h}$, heat loss was significantly greater $(P<0.00 \mathrm{I})$ for the high ration, greater body-weight and lean phenotype, and $\mathrm{N}$ retention greater $(P<0.01)$ for the high ration, lower body-weight and lean phenotype. Thus the experimental design was achieved in so far that there were significant differences between all groups in the way that they partitioned the same two amounts of ME between heat, protein and fat.

In order to calculate the true energy costs of protein and fat deposition it is necessary first to make the reasonable assumption that they are absolute values independent of phenotype or stage of maturity. Then for each phenotype at each body-weight,

$$
M_{\mathrm{E}}=A+b R_{\mathrm{E}, p}+c R_{\mathrm{E}, f}
$$

where $M_{\mathrm{E}}$ is $\mathrm{ME}$ intake and $R_{\mathrm{E}, p}$ and $R_{\mathrm{E}, f}$ are energy retention as protein and fat respectively, all values being expressed in $\mathrm{kJ} / 24 \mathrm{~h}$. Then $b$ and $c$ become the ME required to deposit I kJ of protein and fat respectively and the solution for $A$ is the so-called maintenance requirement for each group at each body-weight.

From the results listed in Table 3 , the solution to equation I becomes:

$$
\begin{gathered}
M_{\mathrm{E}}=A+2.25 R_{\mathrm{E}, p}+\mathrm{I} \cdot 36 R_{\mathrm{E}, f} \quad(\mathrm{RSD} 6.02) . \\
( \pm 0.16) \quad( \pm 0.06)
\end{gathered}
$$

The following were the values obtained for $A(\mathrm{~kJ} / 24 \mathrm{~h})$ :

$$
\begin{aligned}
& \text { fatty, } 200 \mathrm{~g}, A=84^{\circ} \circ \\
& \text { lean, } 200 \mathrm{~g}, A=129.5 ; \\
& \text { fatty, } 35^{\circ} \mathrm{g}, A=\mathrm{I} 22^{\circ} ; \\
& \text { lean, } 35^{\circ} \mathrm{g}, A=\mathrm{I} 2^{\circ} \cdot \mathrm{I} .
\end{aligned}
$$

If the assumption that the energy costs of protein and fat deposition are the same for both body-weights and phenotypes is valid, then the observed wide range of values for heat loss (Table 3 ) should correspond in all circumstances with those predicted from a modification of equation 2 , namely,

$$
H=A+\mathrm{I} \cdot 25 R_{\mathrm{E}, p}+0.36 R_{\mathrm{E}, f}
$$




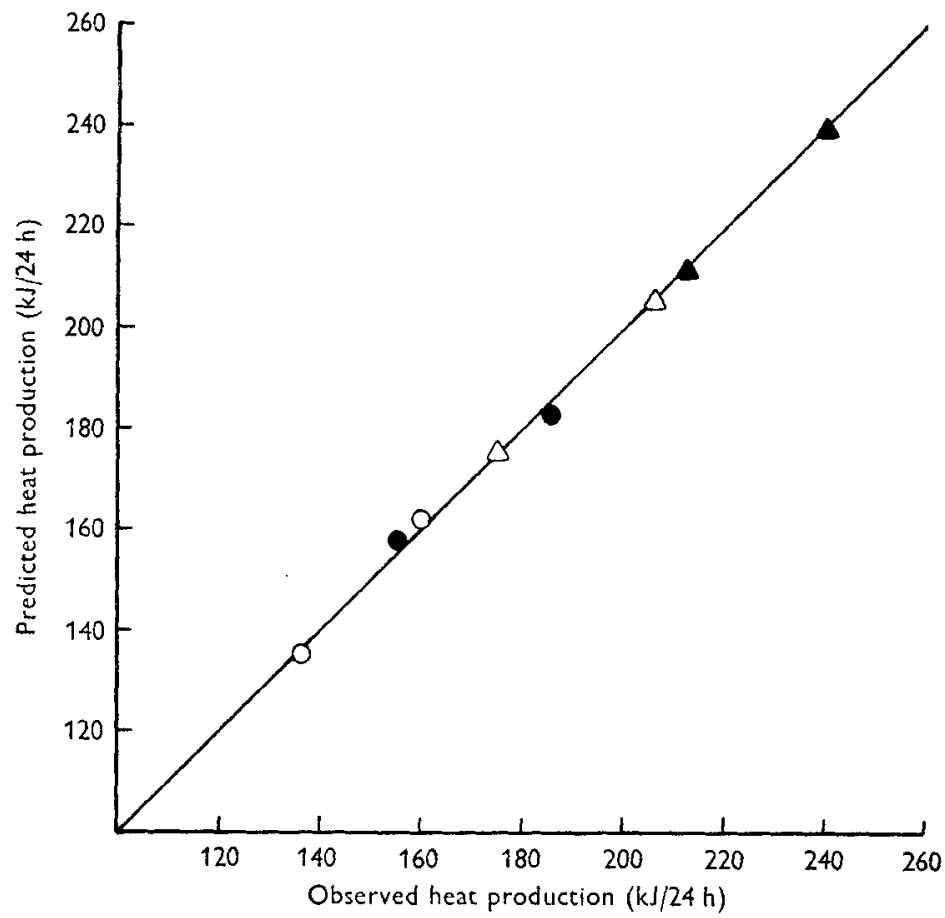

Fig. I. The relationship between observed heat production in lean and congenitally obese (Zucker) rats and that predicted from the equation:

$$
H=A+\mathrm{r} \cdot 25 R_{\mathrm{E}, p}+0.36 R_{\mathrm{E}, f} \text { (see p. 359). }
$$

$\bigcirc$, Fatty rats at $200 \mathrm{~g} ; 0$, at $350 \mathrm{~g} ; \triangle$, lean rats at $200 \mathrm{~g} ; \Delta$, at $350 \mathrm{~g}$.

Fig. I shows that this is so. The agreement at all stages of growth, levels of intake and for both phenotypes is remarkable and we may confidently conclude that the ME requirements for protein and fat deposition in the Zucker rat given a highly digestible diet are 2.25 and 1.36 respectively. Assuming an energy content of 23.5 and $39.3 \mathrm{~kJ} / \mathrm{g}$ for protein and fat this corresponds to an ME requirement of 52.9 and $53.4 \mathrm{~kJ}$ respectively per $\mathbf{g}$ protein and fat deposited, i.e. the ME requirement for deposition of $\mathrm{I} g$ protein and $\mathrm{I} g$ fat are almost identical.

\section{DISCUSSION}

Table 4 lists the most recent estimates of the energy costs of protein and fat deposition in pigs and rats. A more comprehensive list, which includes earlier estimates from the same workers, is given by Kielanowski (1976), who, as indicated earlier, suggested a preferred value of $2 \cdot 32 \mathrm{~kJ} \mathrm{ME} / \mathrm{kJ}$ protein deposition, a value almost identical to that obtained in the present experiment.

All the values listed, with the exception of those from the present experiment, depended on certain assumptions as to the relationship between body-weight and ME requirement for maintenance. It was uncertainties attached to these assumptions that gave rise to the wide discrepancies between earlier estimates of the energy cost of protein deposition (not listed in Table 4 ). Thorbek ( 1970 ), for example, estimated the energy cost of protein deposition to be $\mathbf{2 \cdot 3 2}$ using an empirical estimate of main- 
Table 4. Recent estimates of the metabolizable energy (ME) requirements for protein and fat deposition in pigs and rats

\begin{tabular}{|c|c|c|c|c|c|c|}
\hline \multirow[b]{2}{*}{ Species } & \multirow[b]{2}{*}{ Diet } & \multicolumn{3}{|c|}{$\begin{array}{l}\text { Energy } \\
\text { requirement } \\
\text { (kJ ME/kJ } \\
\text { tissue) }\end{array}$} & \multirow{2}{*}{$\begin{array}{c}\text { Assumed } \\
\text { maintenance } \\
\text { requirement } \\
(\mathrm{kJ} / \mathrm{kg} \mathrm{W} \text { per } 24 \mathrm{~h})\end{array}$} & \multirow[b]{2}{*}{ Source of values } \\
\hline & & $\begin{array}{l}\text { of diet } \\
(\mathrm{kJ} / \mathrm{g} \\
\mathrm{DM})\end{array}$ & $\begin{array}{l}\text { Protein } \\
\text { deposi- } \\
\text { tion }\end{array}$ & $\begin{array}{l}\text { Fat } \\
\text { deposi- } \\
\text { tion }\end{array}$ & & \\
\hline \multirow[t]{5}{*}{ Pigs } & & - & $2 \cdot 80$ & $I \cdot 36$ & $424 W^{0.75}$ & $\begin{array}{l}\text { Kielanowski \& } \\
\text { Kotarbinska (1970) }\end{array}$ \\
\hline & & $16 \cdot 2$ & $1 \cdot 85$ & $1 \cdot 42$ & $375-460 W^{0.75}$ & $\begin{array}{l}\text { Gädeken, Oslage \& } \\
\text { Fliegel (1973) }\end{array}$ \\
\hline & & $14 \cdot 1$ & $\mathrm{I} \cdot 75$ & $I \cdot 45$ & $418 W^{0.75}$ & $\begin{array}{l}\text { Close, Verstegen \& } \\
\text { Mount (1973) }\end{array}$ \\
\hline & $\begin{array}{l}\text { Barley* } \\
\text { Maize* }\end{array}$ & $\begin{array}{l}13 \cdot 4 \\
14.6\end{array}$ & $\begin{array}{l}2 \cdot 05 \\
2 \cdot 19\end{array}$ & $\left.\begin{array}{l}1 \cdot 33 \\
1 \cdot 20\end{array}\right\}$ & $7029+33.4 \mathrm{~W}$ & Thorbek (I975) \\
\hline & Sorghum* & 144 & $\begin{array}{l}r \cdot 98 \\
2 \cdot 06\end{array}$ & $\begin{array}{l}I \cdot 37 \\
I \cdot 40\end{array}$ & $548 \mathrm{~W}$ & Schiemann (1970) \\
\hline \multirow[t]{3}{*}{ Rats } & & - & $1 \cdot 32$ & $I \cdot 32$ & $468 W^{0.75}$ & $\begin{array}{l}\text { McCracken \& Weatherup } \\
\text { (1973) }\end{array}$ \\
\hline & & 134 & $2 \cdot 32$ & $1 \cdot 53$ & $\left.\begin{array}{l}\text { Lean, } 63 \cdot 9+310 \mathrm{~W} \\
\text { Fat, 19.6+380 W }\end{array}\right\}$ & Pullar \& Webster (1974) \\
\hline & & $18 \cdot 3$ & $2 \cdot 25$ & $I \cdot 36$ & Not assumed & Present experiment \\
\hline
\end{tabular}

- Diets were supplemented with proteins, vitamins and minerals.

tenance requirement at the body-weight of the pigs in her experiments, but obtained a value of $\mathrm{I} .06$ using the then preferred formula of Breirem (1939) which states that heat production of pigs at maintenance is $82 \mathrm{I} \mathrm{kJ} / \mathrm{kg}$ body-weight (W) ${ }^{0.56}$.

Kielanowski \& Kotarbinska (1970), Close, Verstegen \& Mount (1973) and McCracken \& Weatherup (1973) all assumed that the maintenance energy requirement of the growing pig was proportional to $W^{0 \cdot 75}$. More recent studies with the pig (Close \& Mount, 1975) and with cattle (Blaxter \& Wainman, I966; Webster, Brockway $\&$ Smith, I974) have confirmed that basal metabolism, and thus maintenance requirement during growth, are related to an exponent of body-weight slightly below, but not significantly different from, the traditional expression for 'metabolic body size' or $\mathrm{W}^{\mathbf{0} 75}$. This was, of course, not originally proposed as a description of the relationship between heat loss and body size in the growing animal, but as an expression which permitted comparison between measurements of basal metabolism in adults of different species differing widely in body size (Kleiber, 196r).

In the experiments of Gädeken et al. (1973), Schiemann (1970) and Thorbek (1975), maintenance energy requirement was assessed empirically from the measurements made of energy balance. However, body-weight still had to be included as a major factor in the multiple regression analysis, and one which was inevitably autocorrelated with the partition of retained energy between fat and protein.

The present study with the Zucker rat did not require that body-weight be included as a variable in regression analysis, but instead made use of the extreme difference between the fatty and lean phenotypes to adjust the proportion of energy retained 
as protein from, for example, $0.064(\mathrm{FL}, 350 \mathrm{~g})$ to $0.43 \mathrm{I}(\mathrm{LL}, 35 \circ \mathrm{g})$ at the same $\mathrm{ME}$ intake and body-weight. The value of $\mathrm{r} \cdot 36 \mathrm{~kJ}$ for the $\mathrm{ME}$ required to deposit $\mathrm{I} \mathrm{kJ}$ energy as fat is very close to the preferred value (ARC/MRC Committee 1974) for simple-stomached species given diets rich in carbohydrate. The value of $2.25 \mathrm{~kJ}$ $\mathrm{ME} / \mathrm{kJ}$ protein is effectively the same as that recommended, with caution, by Kielanowski (1976).

The majority of the estimates given in Table 4 are rather close to the present values of $2 \cdot 25$ and $I \cdot 36$ for protein and fat respectively, which suggests that the assumptions made in estimating maintenance requirement were more or less correct. The good agreement between most of the different estimates of the energy costs of protein and fat deposition indicates that values of 2.3 and $1.4 \mathrm{~kJ} \mathrm{ME} / \mathrm{kJ}$ tissue may be used with confidence as predictors of the ME requirements for protein and fat deposition in simple-stomached species given high-quality diets.

The increments of heat production per $\mathrm{kJ}$ protein and fat deposited, namely about I.3 and 0.4 (equation 3) indicate the amount of work done, or the amount of high-energy phosphate bonds used in their deposition under standard dietary conditions.

Since diets differ in the efficiency with which they can make high-energy phosphate bonds available to support the work of anabolism, one would, a priori, expect to see differences between diets in the ME required to deposit protein and fat. Unfortunately the diets used in the experiments quoted in Table 4 were rather similar in composition and do not permit more detailed analysis of this point. Blaxter (I967) has shown that the efficiency with which the wide range of diets given to ruminants is used for fat deposition is proportional to the ME content of the ration. The results from work with pigs (Table 4) cannot be used to establish whether this concept can be used for simplestomached species, although there is a suggestion from our previous (Pullar \& Webster, 1974) and present work with rats that the efficiency of both protein and fat deposition was slightly improved by increasing the ME content of the diet.

The values given in equation 2 for $A$, the ME requirement associated with zero protein and fat deposition, or so-called maintenance requirement, confirmed our earlier observation that heat losses from fatty Zucker rats were much lower than from lean rats given the same $M E$ intake, and that the difference was much greater than can be accounted for simply in terms of the reduced rate of protein deposition in the fatties. Carcass analysis was not performed on the rats in the present experiments but our previous results (Pullar \& Webster, 1974) and other work in this laboratory (J. D. Radcliffe, unpublished results) indicate that the body protein and fat contents of male fatty and lean Zucker rats at 200 and $35^{\circ} \mathrm{g}$ body-weight and receiving diets similar to those given in these experiments are approximately as follows:

\begin{tabular}{|c|c|c|c|c|c|}
\hline & \multicolumn{3}{|c|}{ Weight (g) } & \multirow{2}{*}{$\begin{array}{l}\text { Maintenance } \\
(\mathrm{A}, \mathrm{kJ})\end{array}$} & \multirow{2}{*}{$\begin{array}{c}A / \text { Unit } \\
\text { protein } \\
(\mathrm{kJ} / \mathrm{g})\end{array}$} \\
\hline & Body & Protein & Fat & & \\
\hline Fatty & $\begin{array}{l}200 \\
350\end{array}$ & $\begin{array}{l}25 \\
45\end{array}$ & $\begin{array}{r}90 \\
160\end{array}$ & $\begin{array}{r}84.0 \\
129.5\end{array}$ & $\begin{array}{l}3 \cdot 4 \\
2 \cdot 9\end{array}$ \\
\hline Lean & $\begin{array}{l}200 \\
350\end{array}$ & $\begin{array}{l}40 \\
70\end{array}$ & $\begin{array}{l}20 \\
35\end{array}$ & $\begin{array}{r}122.7 \\
192.1\end{array}$ & $\begin{array}{l}3 \cdot 1 \\
2 \cdot 7\end{array}$ \\
\hline
\end{tabular}


These values indicate that the maintenance requirement of both fatty and lean rats is more closely related to body protein content (or to lean body-weight) than to total body-weight. Fatties have, however, a slightly higher requirement per $\mathrm{g}$ body protein, and in both phenotypes $A /$ Unit protein declines with increasing maturity. Thus it is not possible, from these experiments, to derive a simple expression that will predict maintenance energy requirement in both fatty and lean rats from one or more measurements of body-weight and composition.

It is not really surprising that the multiplicity of energy-demanding processes that are arbitrarily included within the definition of maintenance requirement should not lend themselves to a simple solution.

It is equally true that the values for the energy costs of protein and fat deposition are arbitrary in nature since they do not describe the total energy costs of synthesis, but simply relate deposition (or the difference between total synthesis and degradation) to increments of ME. The energy cost of synthesizing the protein and fat additional to that which is deposited in the growing body is included within the maintenance requirement. Until reliable measurements can be made of total protein and fat synthesis in the Zucker rat it will not be possible to assess the true contribution of the energy costs of protein and fat synthesis to the energy requirements for growth. Nevertheless, the good agreement that now exists between different estimates of the energy costs of protein and fat deposition in simple-stomached species like the rat and the pig does indicate that these values can now be used with confidence for the important practical business of assessing and providing the nutrient requirements of growing animals.

We are grateful to Mr A. W. Boyne for his advice on matters statistical.

\section{REFERENCES}

ARC/MRC Committee (1974). Food and Nutrition Research report of ARC/MRC Committee, p. $3^{\circ}$. London: H.M. Stationery Office.

Blaxter, K. L. (1967). The Energy Metabolism of Ruminants. London: Hutchinson Scientific and Technical.

Blaxter, K. L. \& Wainman, F. W. (1966). Br. F. Nutr. 20, 103.

Breirem, K. (1 939). Biedermanns Zbl. Tierernähr. Ir, 487.

Close, W. H. \& Mount, L. E. (1975). Br. F. Nutr. 34, 279.

Close, W. H., Verstegen, M. W. A. \& Mount, L. E. (1973). Proc. Nutr. Soc. 32, 72 A.

Gädeken, D., Oslage, H. J. \& Fliegel, H. (1973). Publs Eur. Ass. Anim. Prod. no. 14, p. 169.

Kielanowski, J. (1965). Publs Eur. Ass. Anim. Prod. no. I I, p. I3.

Kielanowski, J. ( 1976). Publs Eur. Ass. Anim. Prod. no. I 5.

Kielanowski, J. \& Kotarbinska, M. (1970). Publs Eur. Ass. Anim. Prod. no. 13, p. I45.

Klieber, M. (196r). The Fire of Life. New York: Wiley Ltd.

McCracken, K. J. \& Weatherup, S. T. C. (1973). Proc. Nutr. Soc. 32, 66 A.

Pullar, J. D. (1969). In International Encyclopedia of Food and Nutrition, vol. 17. Nutrition of Animals of Agricultural Importance, part I, p. 47I [D. Cuthbertson, editor]. Oxford: Pergamon Press.

Pullar, J. D. \& Webster, A. J. F. (1974). Br. F. Nutr. 31, 377.

Schiemann, R. (1970). Wiss. Z. Humbolt-Univ. Berl., Mathematisch-naturwissenschaftliche Reihe I9, 35.

Thorbek, G. (1970). Publs Eur. Ass. Anim. Prod. no. 13, p. 129.

Thorbek, G. (1975). Beretn. St. Husdryrbrugs Forsøg., København no. 424.

Webster, A. J. F., Brockway, J. M. \& Smith, J. S. (1974). Anim. Prod. 19, 127.

Zucker, L. M. \& Zucker, T. F. (I96I). F. Hered. 52, 275. 